\author{
研 究 \\ エリスロマイシンの蝸牛電位への影響 \\ 千葉 敏彦・由嶸*.小林 俊光・高坂 知節

\section{The Effect of Erythromycin on Cochlear Potentials} \\ Toshihiko Chiba, Toshimitu Kobayashi and Tomonori Takasaka \\ (Tohoku University) \\ You Rong \\ (First Teaching Hospital Tianjin College)
}

\begin{abstract}
The mechanism of hearing loss following administration of intravenous erythromycin lactobionate was investigated using the albino guinea pig. This hearing loss was found, for the first time, to be due to cochlear dysfunction caused by erythromycin administration.

The endocochlear potential (EP) and the cochlear microphonics (CM), recorded at the first or second cochlear turn, transiently decreased when erythromycin was administered intravenously at dosages of 100 and $150 \mathrm{mg} / \mathrm{kg}$. The decrease in EP and CM was clearly related to dose. A complete recovery of EP and CM ensued after each erythromycin application. However, perilymphatic perfusion with $3 \mathrm{mM}$ of erythromycin caused an immediate and drastic decrease in $\mathrm{CM}$, while it caused a mild decrease in EP following its initial elevation. The magnitude of the negativity of EP in response to anoxia was small after perilymphatic perfusion, while it remained within the normal range with intravenous application.

These findings suggest that intravenously applied erythromycin has a direct effect upon the stria vascularis, while erythromycin applied via the perilymph exerts its potent action predominantly on the hair cells.
\end{abstract}

Key words : erythromycin, hearing loss, endocochlear potential, cochlear microphonics, stria vascularis

はじめに

エリスロマイシンは1952年に McGuire らによって 開発された，グラム陽性菌に対して強い抗菌力を持つマ クロライド系の抗生物質であるが，副作用の少ない安全 な抗生物質とされ，臨床の場で広く使用されており，特 にマイコプラズマ肺炎やレジオネラ肺炎に対しては第一 選択薬とされてきた。また最近ではびまん性汎細気管支
炎や慢性副鼻腔炎, 出性中耳炎への少量長期投与が有 用とされ頻用されている. 1973年に Mintz ら2)によって エリスロマイシンによる耳毒性が初めて報告されるまで エリスロマイシンは耳毒性のない抗生物質とされてきた。 しかし，その後多くのエリスロマイシンによる難聴例が 報告3) 12) されるようになり，最近になってェリスロマ イシンの耳毒性が注目されるよらになった。

東北大学医学部耳鼻咽喉科学教室

* 天津医学院 
エリスロマイシンによる難聴は $4 \mathrm{~g} /$ 日以上の高濃度 な静脈内投与例に多くみられ，腎障害または肝障害を基 礎疾患として持つことが多いが，肝腎障害がない例でエ リスロマイシンの経口投与 $(1.5 \mathrm{~g} /$ 日) 1 日後に難聴が出 現した例も報告10)されている.エリスロマイシンによ る難聴はアミノ配糖体系抗生物質による難聴が高音障害 から始まるのに対して, 初期から高音域はもちろん可聴 域レベルも障害されるのが特徵である12). 難聴はエリス ロマイシンの投与を停止すれば大部分の例で 6 ～14日以 内に回復する ${ }^{13)}$ が，僅かながら不可逆性難聴例も報 告699)されている．また難聴とともに前庭障害8) や構音 障害3)，複視(3)，急性の精神障害7を伴った症例も報告さ れている. Schweitzer ら5) はェリスロマイシン投与に よる難聴予防のガイドラインとして 1 ．腎機能が悪い 場合はェリスロマイシンの 1 日投与量は $1.5 \mathrm{~g}$ 以下とす べきである， 2 ，高龄の患者もしくは腎機能または肝機 能障害を持つ患者の場合, 治療前後の聴力検査をすべき である，3．フロセマイド，シスプラチンをたはアミ， グリコシド系抗生物質などの耳毒性薬剂が既に投与され ている患者にェリスロマイシンを投与する場合には注意 すべきである，と提唱している.

しかしながら，エリスロマイシンによる難聴の発症機 序は未だ十分に解明されて沏らず，聴覚路の障害責任部 位に関寸る研究は基礎・臨床とも極めて少ない，その中 にあって, Brummett ら ${ }^{14)}$ (1989)はエリスロマイシン投 与を受けたヒトの $\mathrm{ABR}$ はV 波のみの延長を起こすとし て，エリスロマイシンの聴覚障害は中枢性である可能性 を報告した。一方，Sacristan ら15)はヒトで，エリスロ マイシン治療中は I 〜 III波が延長し，V波は不変である が，治療終了後には回復することを示し，より末梢の機 能障害と推測しているものの, 内耳機能についての検討 を行った報告はみられない，そこで今回われわれはエリ スロマイシンによる内耳電位の変化について検討を行っ た.

\section{方 法}

プライェル反射正常の体重 $200 \sim 400 \mathrm{~g}$ の白色モルモ ットを使用した．ネンブタール麻酔下に気管切開し，筋 弛緩・人工呼吸下に管理した。蝸牛骨胞を腹外側より開 放したのち蝸牛を露出した．電位の記録は蝸牛空経由に 基底回転，または蝸牛骨壁に作製した小孔経由に第 2 回 転のそれぞれ中央階に先端 $2 \sim 3 \mu \mathrm{m}$ のガラス管微小電
極 $(150 \mathrm{mM} \mathrm{KC} 1$ 充填) を刺入し, 蝸牛内リンパ直流電 位 $(\mathrm{EP})$ ・蝸牛マイクロフォン電位 $(\mathrm{CM})$ を記録した。 EP の記録には WPI FD223 アンプを用いた．CM の記 録には NF5610B アンプを使用し，外耳道に挿入したイ ヤホン (Erymotic 社製 ER-3A) からの $1 \mathrm{kHz} ，$ 約 $60 \mathrm{~dB}$ SPL の純音を用いた.

エリスロマイシン(ラクトビオン酸エリスロマイシン) の静脈内投与はェリスロマイシン水溶液 $50 \mathrm{mg} / \mathrm{ml}$ を生 理食塩水にて 2 倍に調製したものを使用し，頸静脈また は大腿静脈より $50 \sim 150 \mathrm{mg} / \mathrm{kg}$ を約 $50 \mathrm{mg} / \mathrm{kg} /$ 分の速 度でゆっくり注入した. エリスロマイシンの静注にあた っては最初は頸静脈にカテーテルを留置し投与したが, 静注直後に心機能が悪化し死亡する例がみられたことか ら，途中から投与量が $150 \mathrm{mg} / \mathrm{kg}$ と多い場合には循環 系への負荷の少ない大腿静脈から静注した.

外リンパ灌流は基底回転鼓室階に作製した約 $100 \mu \mathrm{m}$ の小孔を入孔，基底回転前庭階に作製した小孔を出孔と し， $3 \mathrm{mM}$ エリスロマイシン含人工外リンパ夜 $\left(95 \% \mathrm{O}_{2}\right.$ $5 \% \mathrm{CO}_{2}$ で飽和し， $\mathrm{pH} 7.4 \sim 7.6$ 亿調製)を灌流ポンプ (Narishige IM-1)により $10 \mu \mathrm{l} /$ 分の速度で行った.

\section{結果}

1 ）エリスロマイシン静注による $\mathrm{EP}, \mathrm{CM}$ の変化

図 1 は 50,100,150 mg/kg のエリスロマイシン静注 による EP の変化(平均土標準偏差)を示している. 50 $\mathrm{mg} / \mathrm{kg}$ の静注 $(\mathrm{n}=3)$ では EP に汪とんど変化を認めな かった. $100 \mathrm{mg} / \mathrm{kg}$ の静注 $(\mathrm{n}=5)$ では 8 分後に平均

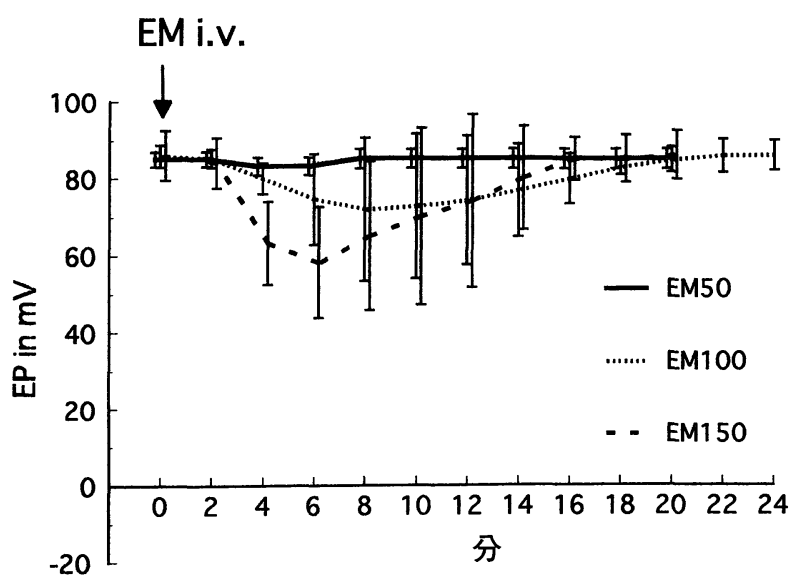

図 $150,100,150 \mathrm{mg} / \mathrm{kg}$ のエリスロマイシンを静注した時の $\mathrm{EP}$ の変化 (平均士標準偏差). $\mathrm{EM}$ : エリスロマイシン. 
$15.6 \pm 19.4 \mathrm{mV}$ 低下したが，20分後には完全に元のレ ベルまで回復した. $150 \mathrm{mg} / \mathrm{kg}$ の静注 $(\mathrm{n}=5)$ では 6 分 後に平均 $33.0 \pm 13.2 \mathrm{mV}$ 低下し, 20 分後に完全回復し た.すなわち EP の変化は, エリスロマイシンの濃度に 依存するといら結果であった. EP が完全回復した後に 人工呼吸器を停止したところ生じた負の EP の大きさは 正常動物のそれと相違はなく, 常に $-30 \sim-40 \mathrm{mV}$ の 十分に絶対値の大きな負の $\mathrm{EP}$ が認められた.

図 2 は土リスロマイシン $150 \mathrm{mg} / \mathrm{kg}$ を静注した 5 例 の EP の変化をそれぞれ示したものであるが，静注開始 約 3 分後より EP は低下し, 動物により多少のばらつき はあるものの $5 \sim 10$ 分後に最低值に到達したのち，20分 後には全例ほぼ元のレベルに回復した.

図 $3(\mathrm{~A}, \mathrm{~B})$ にエリスロマイシン $150 \mathrm{mg} / \mathrm{kg}$ 静注時の $\mathrm{EP}, \mathrm{CM}$ の変化の代表例 2 例を示す。いずれも $\mathrm{CM}$ は $\mathrm{EP}$ の低下とともに $20 〜 30 \%$ 低下した後, 変動はあるも のの EP とともに30分後までにほぼ回復した.

2 ）エリスロマイシン外リンパ灌流による $\mathrm{EP}, \mathrm{CM}$ の変化

図 $4(\mathrm{~A}, \mathrm{~B})$ は外リンパ腔を $3 \mathrm{mM}$ エリスロマイシン 含人工外リンパ液にて灌流したときの $\mathrm{EP}, \mathrm{CM}$ の変化 の代表例 2 例を示している.いずれも $\mathrm{CM}$ は灌流直後 より急激に低下し，20分後にはノイズレベル $(0.5 \%)$ に 低下した。一方，EP は灌流開始直後より一旦上昇し， 灌流前よりも $10 \sim 20 \mathrm{mV}$ 増加し，これをしばらく維持 した後，緩やかに低下し $0 \mathrm{mV}$ に近づいた。 さらに図 4 B では呼吸器を停止しアノキシアを負荷したが負の EP

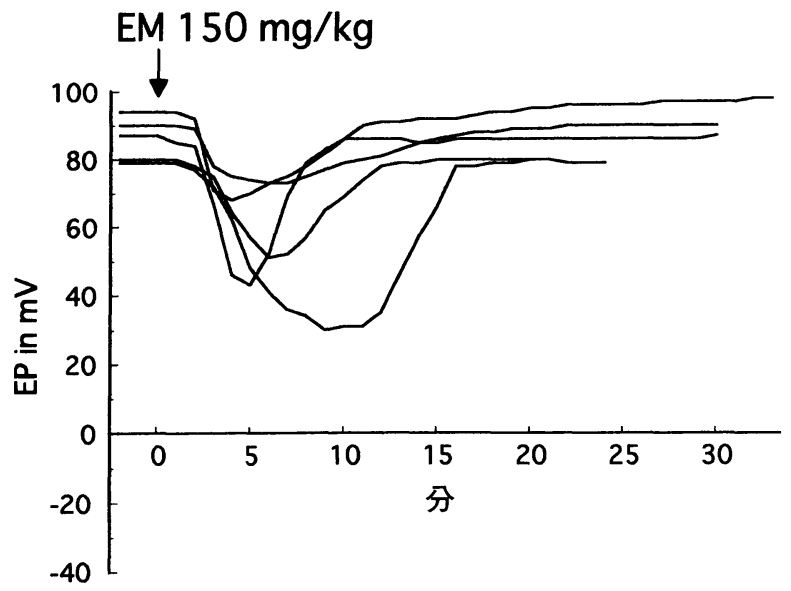

図 2 エリスロマインン $150 \mathrm{mg} / \mathrm{kg}$ を静注した 5 例の $\mathrm{EP}$ の 変化.

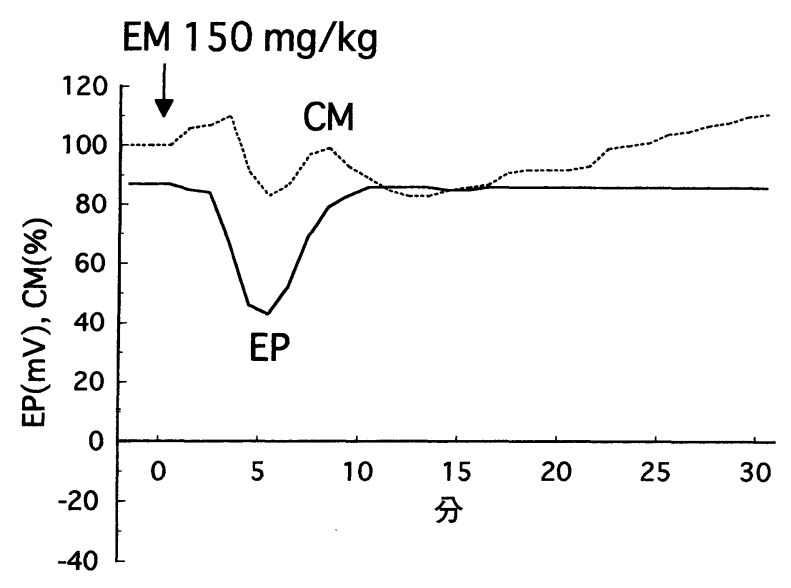

A

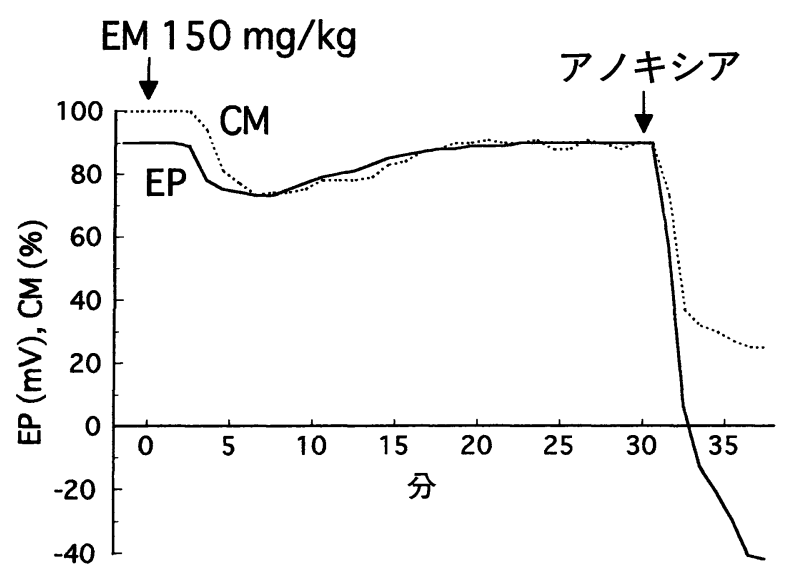

B

図 3 エリスロマイシン $150 \mathrm{mg} / \mathrm{kg}$ 静注時の $\mathrm{EP}, \mathrm{CM}$ の変化 の代表例 2 例 $(A, B)$. Bでは静注後のアノキシア負荷 で正常な負の EP が記録された.

は $-3 \mathrm{mV}$ と著しく絶対值が減少していた.

\section{考察}

エリスロマイシンによる耳毒性は1973年に Mintz ら 2) によって初めて報告されて以来, 今日までに約 47 例が報 告12)されている. しかし, 現在でもアミノ配糖体抗生 斉の耳毒性と比較すると一般臨床家の関心は薄く，その 耳毒性発現機序解明の動物実験の報告例は数えるほどし かない. Stupp ら ${ }^{16)}$ は各種の抗生剤をモルモットの中 耳に局所注入し, 蝸牛の有毛細胞の変化を観察し, 各薬 剤の耳毒性の比較を試みた.この中で 0.1 モルのエリス ロマイシンを 1 日拉きに 3 回注入した時, 蝸牛基底回転 


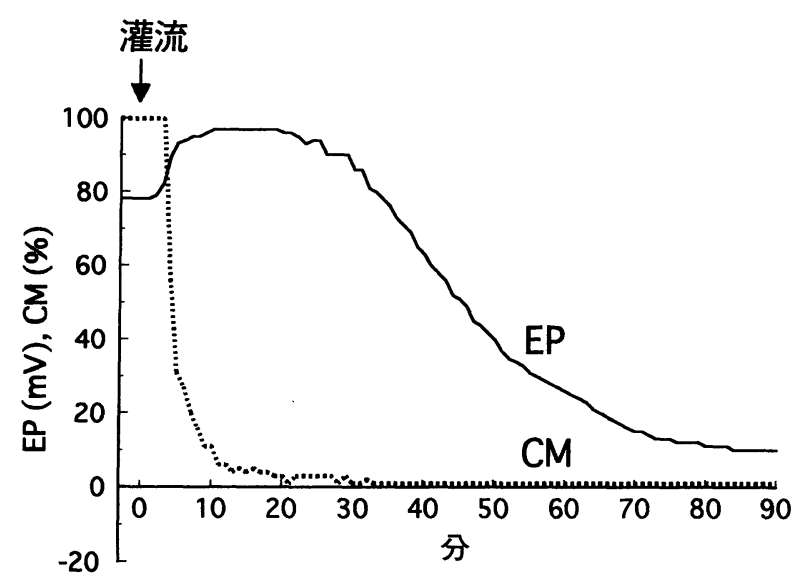

A

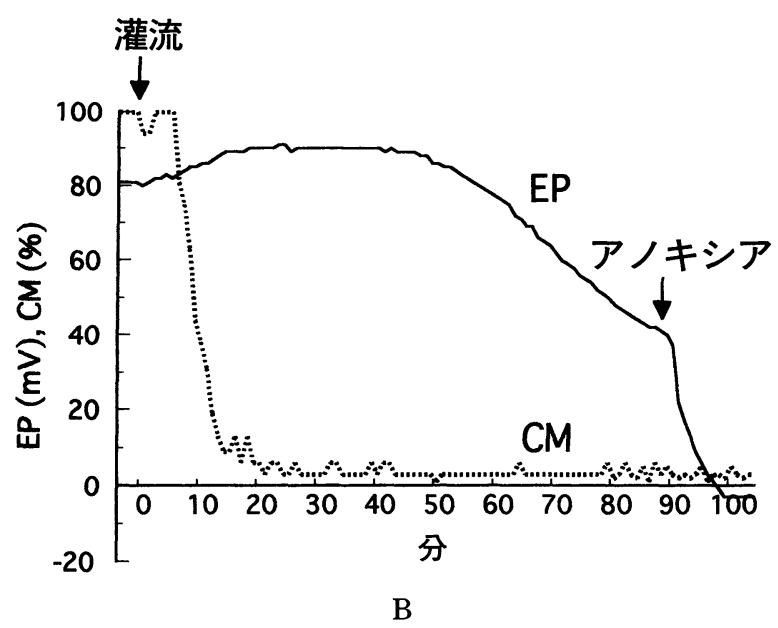

図 $43 \mathrm{mM}$ エリスロマイシン含人工外リンパ夜による外リン パ灌流時の $\mathrm{EP}, \mathrm{CM}$ の変化の代表例 2 例 $(\mathrm{A}, \mathrm{B})$. B で は灌流後のアノキシア負荷で負の EP の絶対值が減少し た。

を中心とした有毛細胞の消失を報告している.しかし， これは今回のよらな内服もしくは静注時の影響を示した ものではなく, 臨床例の報告にみる可逆性の難聴を説明 できる所見ではなかった。

Brummett ら 17) は麻酔したモルモットに $125 \mathrm{mg} / \mathrm{kg} /$ 時でェリスロマイシンを投与すると聴性脳幹反応 (ABR) でまず第 $N$ 波の延長が起こり，次いで他波も延 長するが，エリスロマイシンの投与停止とともに正常化 することを報告した。また Brummett ら18) はモルモッ トに同じく $125 \mathrm{mg} / \mathrm{kg} /$ 時でェリスロマイシンを投与す ると $\mathrm{ABR}$ の第 $\mathrm{N}$ 波が延長した後第正波とII波が消失す
るが， $\mathrm{CM}$ と聴神経複合活動電位 (CAP) には変化のな いことを報告した．また彼らは，エリスロマイシン投与 を受けたヒトの $\mathrm{ABR}$ は第 V波のみ延長することを報告 し，エリスロマイシンによる聴覚障害は中枢性である可 能性を強く示唆した.

Sacristan ら ${ }^{15)}$ はエリスロマイシン投与中の 2 人の患 者の ABR を測定し, エリスロマイシン投与中は $\mathrm{I} \sim \mathrm{II}$ 波が消失したが，投与終了後には正常化したとし， Brummett ら 17)18) とは異なり，より末梢の障害であるこ とを示唆した。

これらに対し, われわれの実験結果はエリスロマイシ ン静注によって内耳電位である $\mathrm{EP}, \mathrm{CM}$ が低下したこ とから，エリスロマイシンによる聴覚障害の責任部位と して内耳障害の可能性を初めて明確に示したものといえ る.エリスロマイシン静注によるEP の低下は投与量に 依存するとともに, 可逆性であることも耳毒性の臨床例 と一致していた. 報告例の多くは $4 \mathrm{~g} /$ 日以上の投与量 で難聴が発症しているが今回のモルモットにおける 100 $\mathrm{mg} / \mathrm{kg}$ といら投与量は七トでは体重 $60 \mathrm{~kg}$ とすると 6 $\mathrm{g}$ であり臨床的投与量との差は小さく，エリスロマイシ ン静注による難聴の主因を内耳とくに血管条の一過性機 能低下に求めることは妥当と考学られる. しかし, 内耳 機能障害に加光て, Brummett ら 17)18) の報告のごとく中 枢性の障害も同時に起こっている可能性は否定できない. 投与量，投与法と末梢および中枢聴覚路のエリスロマイ シンによる受傷性は，今後さらに検討されるべきであろ 5 .

$\mathrm{EP}$ は血管条から能動輸送により生成される約 130 $\mathrm{mV}$ の正の電位とコルチ器由来の約 $-40 \mathrm{mV}$ の負の電 位から構成される．EP の生成については，これまで辺 縁細胞がその重要な役割を担うと考えられてきたが，最 近ではむしろ基底細胞や中間細胞にその中心的役割があ るとする報告19) もなされている. 一方， CM は有毛細 胞を発生源とする音刺激に対応したマイクロフォン電位 であるが，それが正常に維持されるためには有毛細胞が 正常であるのみならず EP，すなわち血管条機能が正常 であることが必要である。 EP, CM はェリスロマイシ ンの投与量に比例して抑制された。また，CM の低下な らびに回復は EP の変化と平行したことから有毛細胞の 障害といらょりは EP の低下に伴ら二次的なものと考光 られた。

一方， $3 \mathrm{mM}$ エリスロマイシンの外リンパ灌流では 
$\mathrm{CM}$ は灌流開始直後から急速に減少してノイズレベルま で減少したのに対し，EPは一旦上昇した後緩徐に減少 し $0 \mathrm{mV}$ へ近づくといらように $\mathrm{EP} と \mathrm{CM}$ の間に動態の 相違がみられた。 なたアノキシア負荷後の負の EP は $-3 \mathrm{mV}$ と絶対值が著しく減少した.この結果は外リン パ灌流ではェリスロマイシンが直接有毛細胞に作用し， 血管条障害よりも早期に有毛細胞障害を及ぼした結果, $\mathrm{CM}$ が消失したものと考えられた。 また同時に有毛細胞 の障害によりアノキシア負荷後の負の EP の絶対値の減 少となったものと考えられる.これに対して $\mathrm{EP}$ は初期 には低下せずむしろ一過性に上昇した．これは負の $\mathrm{EP}$ の絶対値の減少に伴い見かけ上 EP が上昇したものと解 釈できる。このような $\mathrm{EP}$ 上昇， $\mathrm{CM}$ 低下のパターンは バナジン酸塩を外リンパ腔へ投与した場合の各電位の反 応様式20)ときわめて類似して扣り，エリスロマイシン も外リンパ腔への投与では血管条よりも有毛細胞への作 用を強く及洔すのと解釈でさる。

\section{結論}

1 ）エリスロマイシンによる難聴の発現機序の解明の ためにモルモットに $50 \sim 150 \mathrm{mg} / \mathrm{kg}$ のエリスロマイシ ンを静注し $\mathrm{EP}, \mathrm{CM}$ を指標として蝸牛機能の変化を観 察した。また併せて $3 \mathrm{mM}$ エリスロマイシン含人工外 リンパ液による外リンパ灌流を行った。

2) 100 执よび $150 \mathrm{mg} / \mathrm{kg}$ のエリスロマイシン静注で EP 扣よび CM が低下したが，20分後には完全に回復し た。エリスロマイシン静注による難聴の主因は一過性の 血管条機能の低下によるものと考えられた.

3 ）外リンパ腔へのエリスロマイシンの灌流は EP の 一過性上昇とそれにつづく緩徐な低下をひき起こした。 $\mathrm{CM}$ は灌流開始直後より急激に低下したことから, 有毛 細胞に強い障害を起こすものと考えられた.

\section{謝辞}

本研究は平成 6 年度文部省科学研究費補助金 (一般研究 (B) 06454482)の助成によって行った. な拉, 実験コンピューター システムの確立にご協力頂きました東北労災病院耳鼻咽喉科部 長大山健二博士に感謝いたします。

\section{参考文献}

1) McGuire JM, Bunch RL, Anderson RC, et al : "Ilotycin", a new antibiotic. Antibiot Chemother $2: 281 \sim 284,1952$.
2) Mintz U, Amir J, Pinkhas J, et al : Transient perceptive deafness due to erythromycin lactobionate. JAMA 255 : 1122 1123, 1973.

3 ) Taylor R, Schofield IS, Ramos JM, et al : Ototoxicity of erythromycin in peritoneal dialysis patients. Lancet 2 : 935 936, 1981.

4) Kroboth PD, McNeil MA, Kleeger A, et al : Hearing loss and erythromycin pharmacokinetics in a patient receiving hemodialysis. Arch Intern Med 143 : 1263 1265, 1983.

5 ) Schweitzer VG and Olson NR : Ototoxic effect of erythromycin therapy. Arch Otolaryngol $110: 258 \sim 260$, 1984.

6) Levin G and Behrenth E : Irreversible ototoxic effect of erythromycin. Scand Audiol $15: 41 \sim 42,1986$.

7 ) Umstead GS and Neumann KH : Erythromycin ototoxicity and acute psychotic reaction in cancer patients with hepatic dysfunction. Arch Intern Med 146:897 899, 1986.

8 ) Agusti C, Ferran F, Gea J, et al : Ototoxic reaction to erythromycin. Arch Intern Med $151: 380,1991$.

9 ) Dylewski J : Irreversible sensorineural hearing loss due to erythromycin. Can Med Assoc J 139 : 230 231, 1988.

10) Kemp E, Keiar S and Brook JG : Sensorineural hearing loss with low dose erythromycin. Br Med J 302 : 1341, 1991.

11) Swanson DJ, Sung RJ, Fine MJ, et al : Erythromycin ototoxicity; prospective assessment with serum concentrations and audiograms in a study of patients with pneumonia. Am J Med $92: 61 \sim 68,1992$.

12) Brummett RE : Ototoxic liability of erythromycin and analogues. Otolaryngol Clin North Am $26: 811 \sim 819$, 1993.

13) Chiodo AA and Alberti PW : Experimental, clinical and preventive aspects of ototoxicity. Eur Arch Otorhinolaryngol $251:$ 375 392, 1994.

14) Brumett RE, Morrison $R$ and Matthews $J$ : Possible site of action of erythromycin ototoxicity in the human (abstract). Presented at Association for Research in Otolaryngology in Tampa, Flolida, 1989.

15) Sacristan JA, De Cos MA, Sito J, et al : Ototoxicity of erythromycin in man; electrophysiologic approach. Am J Otol $14:$ 186 188, 1993.

16) Stupp H, Kupper K, Lagler F, et al : Inner ear concentrations and ototoxicity of different antibiotics in local and systemic application. Audiology $12: 350 \sim 363,1973$.

17) Brummett RE, Hager G, Fox KE, et al : Erythromycin induced ototoxicity (abstract 36). Presented at Association for Research in Otolaryngology, Midwinter Meeting, pp 25, 
1984.

18) Brummett $\mathrm{RE}$ and Fox $\mathrm{KE}$ : Vancomycin and erythromycin induced hearing loss in humans. Antimicrob Agents Chemother 33 : 791 796, 1989.

19) Wangemann $P$, Liu $J$ and Marcus DC : Ion transport mechanisms responsible for $\mathrm{K}^{+}$secretion and transepithelial voltage across marginal cells of stria vascularis in vivo. Hear Res $84: 19 \sim 29,1995$.
20) Marcus DC, Demott JE, Kobayashi T, et al : Specificity of action of vanadate to the organ of corti. Hear Res $5: 231$ $\sim 243,1981$.

$$
\left.\begin{array}{l}
\text { 原稿採択 : 平成 } 7 \text { 年 } 5 \text { 月 } 2 \text { 日 } \\
\text { 原稿採択 : 平成 } 7 \text { 年 } 7 \text { 月 } 19 \text { 日 } \\
\text { 別刷請求先 : 千葉敏彦 } \\
\text { 干 } 980 \text { 仙台市青葉区星陵町1-1 } \\
\text { 東北大学医学部耳鼻咽喉科学教室 }
\end{array}\right)
$$

